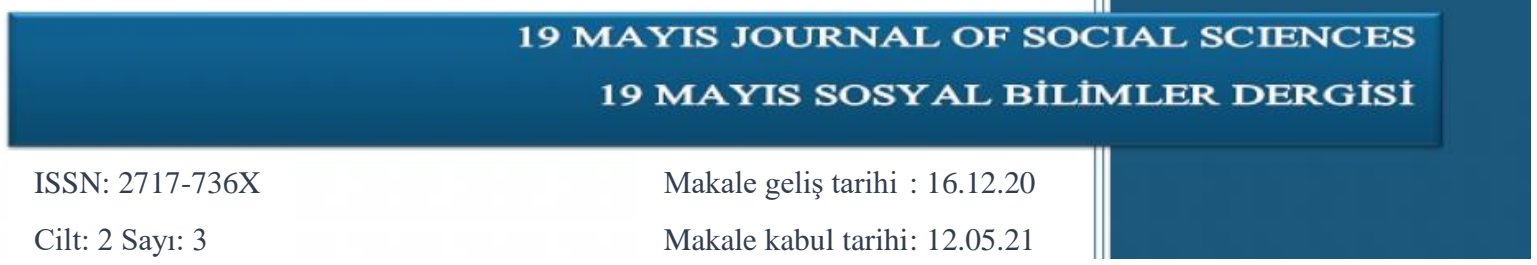

\title{
FACTORS RESPONSIBLE FOR CURRENT ACCOUNT DEFICITS IN TURKEY: SHORT-TERM CAPITAL INFLOWS, ENERGY IMPORTS OR GOLD IMPORTS? \\ İsmail Erkan ÇELİK
}

\author{
Assistant Professor, \\ Doğuş University
}

Faculty of Economics and Administrative Sciences

Department of Economics

erkancelik@dogus.edu.tr

ORCID: 0000-0002-2274-0750

\section{Melih Sefa YAVUZ}

\author{
Research Assistant
}

Beykent University

Faculty of Economics and Administrative Sciences

Business Administration

sefayavuz@beykent.edu.tr

ORCID: 0000-0003-1085-5304

\begin{abstract}
This study investigates the effects of gold imports, energy imports and short-term capital inflows on current account deficits using Turkish quarterly data for the period 1996Q12021Q1. To this end, first, the current account deficit model is built based on the literature review and estimated using the autoregressive distributed lag (ARDL) model. Then the presence of cointegration among relevant variables is tested by employing bounds testing, and then the error correction model is estimated. The bounds testing results indicate cointegration among current account deficits, gold imports, energy imports, portfolio investment, foreign direct investment, reel effective exchange rate, real gross domestic products, openness, and financial development. The empirical findings of this study reveal that while gold imports play a significant deteriorating role on Turkish current account deficits in the short and in the long term, energy imports and portfolio investment only have a short-term effect. Furthermore, appreciation of Turkish currency seems to increase current account deficits only in the long term; it has no short-term effect. Interestingly, the openness proxy, which is being used as a
\end{abstract}


measure of international trade integration of a country to the world economy, exerts no effect on current account deficits neither in the long-term and nor in the short-term.

Keywords: Current Account Deficits, ARDL Bounds Testing, ECM.

JEL Code: F30, F32, G10, E60.

\section{INTRODUCTION}

Current account deficits have always been a hot topic of policy discussions in Turkey. As well known, current account deficits are the main reason behind the economic crisis in developing countries. In particular, the Turkish economy has experienced chronic current account deficits (CAD) over its history with a few years' exceptions. It can be said that the CAD problem of the Turkish economy became more pronounced, especially after the January 24, 1980 decisions that involved the open economy transformation policies. Moreover, with the financial liberalization policies began in 1989, the share of capital flows in current transactions increased sharply. Inevitably, the growth of the economy put pressure on energy imports and CAD due to the country's dependence on oil imports. When the CAD (\% GDP) variable of Turkey between 1995-2020 periods is examined, it is negative except for the years $1998(0,725), 2001$ $(1,864), 2019(0,888)$ (Bari, 2021). Except for the aforementioned three years, the country has consistently run a CAD deficit. When the data in the related period is examined excluding gold and energy, a positive balance is seen in the current account, excluding a few periods. In terms of the Turkish economy, short-term capital movements, gold, and oil imports are seen as important factors in terms of CAD.

In the literature, a number of factors have been suggested as determinants of current accounts deficits in Turkey. Yücel (2003) found that the changes in the growth rate, exchange rate, terms of trade, and central bank reserves were essential determinants of the current account balance for the Turkish economy. Erkılıç (2006), on the other hand, argued that the most important and statistically significant variables responsible for CADs are real exchange rate, growth rate, and CAD of the previous period. Erdogan and Bozkurt (2009) have concluded that the exchange rate, M2 money supply, exchange rate uncertainty, inflation, and the export-import coverage ratio have a significant effect on the CADs. However, it has been stated that the most critical determinants affecting CAD are oil prices and the ratio of exports to imports. In the results of the research conducted by İrhan et al. (2011), the depreciation of the real exchange rate had strongly and significantly improved the trade balance, while the domestic real income negatively affected the trade balance. However, as a result of the increase in external real income, the trade balance has improved significantly, while no significant effect has been observed on crude oil prices. Gacener Atış and Saygılı (2014) foundthat the growth rate and terms of trade are the most important factors affecting Turkey's CAD.

The study of Topalli and Doğan (2016) states that the most important determinants of the CAD in Turkey are energy consumption, openness ratio, gross domestic product, exchange rate, and investments. According to Korucu Gümüşoğlu and Alçın (2019), a positive and significant relationship was found between capital flows and CAD. A negative and meaningless relationship was found between capital flows and foreign direct investments. According to the 
findings of Yurdakul and Cevher (2015), the variable that has the highest impact on the $\mathrm{CAD} / \mathrm{GDP}$ is the real effective exchange rate, followed by the growth rate, energy imports, and openness. The variable with the least impact is foreign direct investment. Barbaros et al. (2020) found that short-term capital inflows cause CADs, and $10 \%$ increase in short-term capital inflows increases the CAD by $3.47 \%$.

As seen above, although different factors have been used to examine the reasons behind chronic CADs in Turkey, the impact of gold imports on CAD has not been investigated yet in the available empirical literature. Additionally, most of the existing studies on the subject examined the impact of only a small number of determinants of CAD.

This study estimates CA model which involves important factors, including gold imports employed in the literature. The rest of this study is organized as follows. Section 2 reviews the empirical literature on the determinants of current accounts deficits. Section 3 introduces data and the methods employed in the empirical analysis in this paper. Section 4 provides estimation results obtained from ARDL CAD model. Section 5 concludes.

\section{DETERMINANTS OF CURRENT ACCOUNT DEFICITS: EMPIRICAL LITERATURE REVIEW}

In the CAD literature, several studies aim to investigate the underlying factors behind the CADs. Bitzis et al. (2008) examined the factors affecting the CAD in the Greek economy in their study. As a result, they concluded that the budget deficit, oil prices, and real effective exchange rate had a positive effect on the $\mathrm{CAD}$, while the interest rate, transportation prices and foreign trade balance had a negative effect on the CAD.

Demirbaş et al. (2009) analysed the relationship between oil prices and CAD for Turkey for the period 1984-2008. Cointegration and VECM methods were used in the analysis and the results of the study showed that an increase in oil prices increased the CAD.

İrhan et al. (2011) analyzed the determinants of the trade balance of the Turkish economy in the period of 1990:Q1-2007:Q3. Researchers used the contemporaneous ARDL-based bounds test to examine the existence of a long-run cointegration relationship between the variables. The estimation results showed that while the depreciation in the real exchange rate strongly and significantly improved the trade balance, domestic real income negatively affected the trade balance, the increase in external real income led the trade balance to improve strongly. No significant effect of crude oil prices was observed.

Demir (2013) tried to analyze the nature and direction of the relationship between industrial production, $\mathrm{CAD}$ and energy imports employing cointegration, error correction model and Granger causality test within the scope of VAR analysis for the Turkish economy over the period 1987-2012. According to the findings, the direction of causality in Turkey is one-way causality goes from industrial production and energy imports to the CAD.

Yurdakul and Cevher (2015) examined the causality relationships between the macro variables affecting the CAD in the Turkish economy and the variables of CAD/GDP, growth rate, real effective exchange rate, foreign direct investment, openness and used energy imports. In the 
study, conditional and partial Granger causality test was applied by using quarterly data covering 2003:1-2014:2 periods. The results of the study show that the variable that has the most impact on the CAD/GDP is the real effective exchange rate, followed by the growth rate, energy imports and openness. It has been determined that the variable with the least effect is foreign direct investments.

Uysal et al. (2015) applied Johansen cointegration analysis based on the VAR model established by using the growth, energy consumption, and CAD data of 1980-2012. In addition, impulseresponse analysis and variance decomposition were performed on the variables. As a result of the analysis, it was concluded that the variables act together in the long run in Turkey.

Topalli and Doğan (2016) investigated the CAD dynamics and sustainability of the Turkish economy in the period 1990:Q1-2014Q2 using the Markov-switching method. According to the results of the research, the variables that affect the CAD the most are energy consumption, openness ratio, gross domestic product, exchange rate and investments.

Kurniadi et al. (2018) analyzed the CAD in Indonesia using the Error Correction Mechanism (ECM) approach between the quarters 2000:1-2015:4. The results of the study show that CAD is negatively affected by real gross domestic product in the long run, while CAD is positively affected by real gross domestic product, real effective exchange rate, and open economy in the short run. It is adversely affected by inflation.

Sarıtaş et al. (2018), using CAD, growth rate, and energy import data, within the scope of VAR (Vector Autoregression Model) model, impact-response analysis, Granger causality analysis, and variance decomposition tests were applied. According to the findings obtained in the study, it has been determined that energy imports are the granger cause of the CAD. The results of the impulse-response analysis show that a shock in energy imports affects GDP positively and significantly for two periods. In the variance decomposition tests related to the CAD variable, it was concluded that energy imports had the highest share in explaining the CAD, while growth had a lower share compared to energy imports.

Korucu Gümüşoğlu and Alçın (2019) investigated the effects of short-term capital flows and foreign direct investments on CAD using the vector autoregression (VAR) model and impulse responses in their study. In the research, they used the 1998-2015 quarterly data of the Turkish economy. As a result, while a positive relationship was found between capital flows and CAD, they found a negative and meaningless relationship between capital flows and foreign direct investments.

Ağır et al. (2020) examined the relationship between energy consumption, economic growth and CAD by using Turkey's annual data for the period 1974-2015. VAR analysis was used in the study. According to the results of the analysis, it has been determined that the CAD is caused by energy demand, contrary to economic growth.

Sahoo et al. (2020) examined the effects of gold and oil exports on the CAD in the Indian economy using linear cointegration techniques for the 37-year period between 1980-2017. The findings of the study revealed a positive and significant effect between crude oil imports and 
current account balance (CAB). It was concluded that there is a negative and significant relationship between gold imports and $\mathrm{CAB}$.

Aka (2020) tried to identify the determinants of the CAD in Turkey by using the 1990-2018 annual data and the least-squares method. The findings of the study show that the ratio of exports to imports, foreign direct and portfolio investments decrease the CAD, while the openness ratio increases the CAD.

Baş and Kara (2020) examined the relationship between CAD and macroeconomic factors such as real GDP, real effective exchange rate index, crude oil prices, and interest rate $(\mathrm{O} / \mathrm{N})$ with 2003:Q4-2018:Q2 data in Turkey. According to the findings of the study conducted using the ARDL limit test, it has been determined that macroeconomic factors and the CAD are cointegrated in Turkey. It has been determined that there is a statistically and economically significant relationship between economic growth (GDP) and CAD in the long run and a statistical relationship between the interest rate $(\mathrm{O} / \mathrm{N})$ and crude oil prices and CAD variables in the short run.

\section{THE MODEL AND THE DATA}

This section introduces the empirical CAD model, dataset and methodology employed in estimation of the model. Having reviewed the literature in previous section, CAD can be modelled as a function of gold imports, energy imports, portfolio investment, and control variables. The control variables of the model include real effective exchange rate, real gross domestic product, openness proxy and financial development proxy. In this respect, the empirical CAD model is constructed as follows:

$$
\begin{gathered}
C A D_{t}=\beta_{0}+\beta_{1} G M_{t}+\beta_{2} E M_{t}+\beta_{3} P I_{t}+\beta_{4} F D I_{t}+\beta_{5} R E X_{t} \\
\quad+\beta_{6} R G D P_{t}+\beta_{7} O P_{t}+\beta_{8} F D_{t}+\varepsilon_{t}
\end{gathered}
$$

where,

$C A D_{t}$ : Current account balance as a percentage of GDP

$G M_{t}$ : Net gold imports as a percentage of GDP

$E M_{t}$ : Net energy imports (crude oil and gas) as a percentage of GDP

$P I_{t}$ : Portfolio investment as a percentage of GDP.

$F D I_{t}$ : Long-term capital inflows as a percentage of GDP

$R E X_{t}$ : Logarithm of Reel effective exchange rate

$R G D P_{t}$ : Logarithm of Real Gross Domestic Product

$O P_{t}$ : Openness proxy defined as the ratio of total trade (export plus imports) to GDP.

$F D_{t}$ : Financial development proxy measured by the ratio of M2 money supply to GDP

$\varepsilon_{t}$ : Stochastic error term.

The data used in the empirical analysis of equation (1) involves quarterly time series data for the period 1996Q1-2021Q1. It is obtained from Central Bank of Turkey's electronic data delivery system. The sample period is determined by the availability of the data. The data subject to empirical analysis is seasonally adjusted. 


\section{Unit root tests}

The first step in econometric analysis with time series data is to determine the level of integration of series because regression with non-stationary variables may lead to spurious regression. In particular, the ARDL approach will produce meaningless results if series included in the mode is integrated of second order (that is I(2) series)..

This study uses three different unit root tests, the Augmented Dicker-Fuller (ADF), the PhilipsPerron (PP) and the Kwiatkowski, Phillips, Schmidt, and Shin (KPSS) test namely, to determine whether variables subject to empirical analysis is non-stationary or to determine the integration level of series. It is worth tho mention that the null hypothesis of the ADF and the PP tests is that a series has a unit root, the null hypothesis for KPSS test is that a series is stationary. Table 1 presents results from the unit root tests.

The findings of unit root tests show that while CAD, EM, FD, OP, RGDP variables are I(1) variables (they become stationary at the first difference), FDI, GM and PI variables are I(0) variables that they are stationary at level according to all three unit root tests. However, REX variable is I(1) variable according to ADF and PP tests but KPSS test indicate that it is $\mathrm{I}(0)$ variable.

Table 1. Unit Root Test Results

\begin{tabular}{|c|c|c|c|c|c|c|c|}
\hline \multirow[b]{2}{*}{ VARIABLE } & \multicolumn{3}{|l|}{ LEVEL } & \multicolumn{3}{|c|}{ FIRST DIFFERENCE } & \multirow[b]{2}{*}{ INFERENCE } \\
\hline & $\mathrm{ADF}$ & $\mathrm{PP}$ & KPSS & $\mathrm{ADF}$ & PP & KPSS & \\
\hline CAD & $-1.907(9)$ & $-2.575(8)$ & $0.439(9)^{* * *}$ & $-4.197(8 *)$ & $-7.916(9)^{*}$ & $0.098(9)$ & $\mathrm{I}(1)$ \\
\hline EM & $-2.264(0)$ & $-2.380(2)$ & $0.579(8) * *$ & $-9.977(0)^{*}$ & $-10.000(4)^{*}$ & $0.113(5)$ & $\mathrm{I}(1)$ \\
\hline FD & $-1.356(0)$ & $-1.281(9)$ & $1.173(8)^{*}$ & $-11.511(0)^{*}$ & $-11.630(5)^{*}$ & $0.078(12)$ & $\mathrm{I}(1)$ \\
\hline $\mathrm{OP}$ & $-1.300(0)$ & $-0.768(25)$ & $1.032(8)^{*}$ & $-9.683(0)^{*}$ & $-9.851(6)^{*}$ & $0.240(54)$ & $\mathrm{I}(1)$ \\
\hline RGDP & $1.191(1)$ & $1.647(12)$ & $1.190(8)^{*}$ & $-14.234(0)^{*}$ & $-14.473(3)^{*}$ & $0.348(10)$ & $\mathrm{I}(1)$ \\
\hline REX & $-2.507(0)$ & $-2.528(19)$ & $0.300(8)$ & $-7.564(3)^{*}$ & $-11.959(5)^{*}$ & & $\mathrm{I}(0)$ or $\mathrm{I}(1)$ \\
\hline FDI & $-6.839(0)^{*}$ & $-6.890(4)^{*}$ & $0.181(5)$ & & & & $\mathrm{I}(0)$ \\
\hline GM & $-4.730(0)^{*}$ & $-4.677(3)^{*}$ & $0.226(7)$ & & & & $\mathrm{I}(0)$ \\
\hline PI & $-2.922(3) * *$ & $-5.565(8)^{*}$ & $0.246(4)$ & & & & $\mathrm{I}(0)$ \\
\hline
\end{tabular}

Note: $* * *, * * *$ indicate statistical significance at $1 \%, 5 \%$, and $10 \%$ level respectively. Figures in parenthesis represent the lag length based on SIC (Schwarz Information Criteria) in ADF regression, Bandwidth (Newey-West automatic) using Bartlett kernel in PP and KPSS tests.

\section{ARDL bounds testing for cointegration}

Having found that some of the variables subject to empirical analysis are non-stationary and they are integrated of different orders, the Engle and Granger $(1987)$ or Johansen $(1988 ; 1995)$ and Johansen and Juselius (1990) multivariate cointegration techniques cannot be used to test for long-run relationship among variables in equation (1). When variables are $\mathrm{I}(0)$ or $\mathrm{I}(1)$ or a combination of both, ARDL cointegration method (or bound cointegration technique) developed by Pesaran and Shin (1999) and Pesaran, Shin and Smith (2001) provides robust and efficient estimates in testing for cointegration. 
ARDL model has many advantages over alternative cointegration methods (Nkoro and Uko, 2016; Nurudeen, 2017): (i) the ARDL technique enables us to handle the dynamic nature of time series adequately allowing each variable having different optimal lags; (ii) it provides robust estimates for a cointegration relationship in small samples as well; (iii) the ARDL model assumes a single reduced form relationship between the dependent and independent variables; (iv) and allows to estimate both long-run and short-run parameters of the model simultaneously.

To test for cointegration using ARDL method, we first constructed an appropriate ARDL model as given in Equation (2) below. As seen from Equation (2), the ARDL model is a linear time series model in which the dependent variable is formulated as a function of lagged values of dependent variable and both contemporaneous and lagged values of independent variables. Table 2 presents the estimation results of Equation (2). The lag length of both dependent and independent variables in Table 2 is determined by using Akaike Information Criterion (AIC).

$$
C A D_{t}=\alpha_{0}+\sum_{i=1}^{p} \alpha_{i} C A D_{t-i}+\sum_{j=1}^{k} \sum_{l_{j} i=0}^{q} \beta_{j, l_{j}} X_{j, t-l_{j}}+\varepsilon_{t}
$$

where $\varepsilon_{t}$ is stochastic error term, $\alpha_{0}$ is a constant term, $\alpha_{i}{ }^{\prime} s$ are the coefficients of lags of dependent variable, and $\beta_{j, l_{j}}$ 's are coefficients of independent variable at time t and $t-l_{j} . X_{t}=$ $\left(G M_{t}, E M_{t}, P I_{t}, F D I_{t}, R E X_{t}, R G D P, O P_{t}, F D_{t}\right)^{\prime}$ represents independent variables in equation (1).

Table 2. ARDL Model Estimation Results

\begin{tabular}{|l|l|l|l|}
\hline Variable & Coefficient & Std. Error & t-Statistic \\
\hline CAD(-1) & $0.681^{*}$ & 0.063 & 10.811 \\
\hline EM & $-0.527^{* * *}$ & 0.293 & -1.799 \\
\hline EM(-1) & 0.425 & 0.264 & 1.609 \\
\hline GM & $-0.967^{*}$ & 0.187 & -5.165 \\
\hline GM(-1) & $0.328^{* * *}$ & 0.203 & 1.620 \\
\hline PI & 0.114 & 0.136 & 0.843 \\
\hline PI(-1) & -0.039 & 0.128 & -0.303 \\
\hline PI(-2) & $-0.273^{* *}$ & 0.133 & -2.056 \\
\hline FDI & -0.068 & 0.048 & -1.428 \\
\hline FDI(-1) & -0.073 & 0.053 & -1.369 \\
\hline FDI(-2) & -0.062 & 0.052 & -1.176 \\
\hline FDI(-2) & $0.159^{*}$ & 0.054 & 2.970 \\
\hline RGDP & $-18.744^{*}$ & 6.333 & -2.960 \\
\hline RGDP(-1) & 8.453 & 6.182 & 1.367 \\
\hline RGDP(-2) & -2.861 & 4.587 & -0.624 \\
\hline RGDP(-3) & -1.687 & 4.902 & -0.344 \\
\hline RGDP(-4) & $15.777^{*}$ & 4.883 & 3.231 \\
\hline REX & $-4.160^{*}$ & 1.279 & -3.254 \\
\hline OP & 0.077 & 0.048 & 1.608 \\
\hline FD & $-0.091^{*}$ & 0.021 & -4.350 \\
\hline FD(-1) & $0.067^{*}$ & 0.023 & 2.934 \\
\hline C & $16.696^{* * *}$ & 8.614 & 1.938 \\
\hline & \multicolumn{2}{|l|}{ Diagnostic Statistics } & \\
\hline R-squared & 0.912877 & ARSQ & 0.888482 \\
\hline
\end{tabular}




\begin{tabular}{|l|l|l|l|} 
S.E. of regression & 0.941026 & HET HARVEY(21) & 18.45919 \\
\hline F-statistic & $37.42137^{*}$ & RESET F TEST & 0.292 \\
\hline BP SERIAL Kİ(2) & 1.163311 & JB NORMALITY & 1.14004 \\
\hline
\end{tabular}

Note: $* * *, * * *$ indicate statistical significance at $1 \%, 5 \%$, and $10 \%$ level respectively. Heteroscedasticity (21) is tested using Harvey Test.

The examination of diagnostic statistics in Table 2 shows that the ARDL model explains about $91 \%$ of change in dependent variable CADs. The error terms of the model have no sign of autocorrelation or heteroscedasticity. Jaque-Berra test indicates that error terms are normally distributed and the RESET test imply that the estimated model stability. Since the CUSUM plot in Figure 1 shows that the cumulative sum of recursive residuals are within the boundaries, it also confirms that the model is stable.

Figure 1. Plot of Cumulative Sum of Recursive Residuals

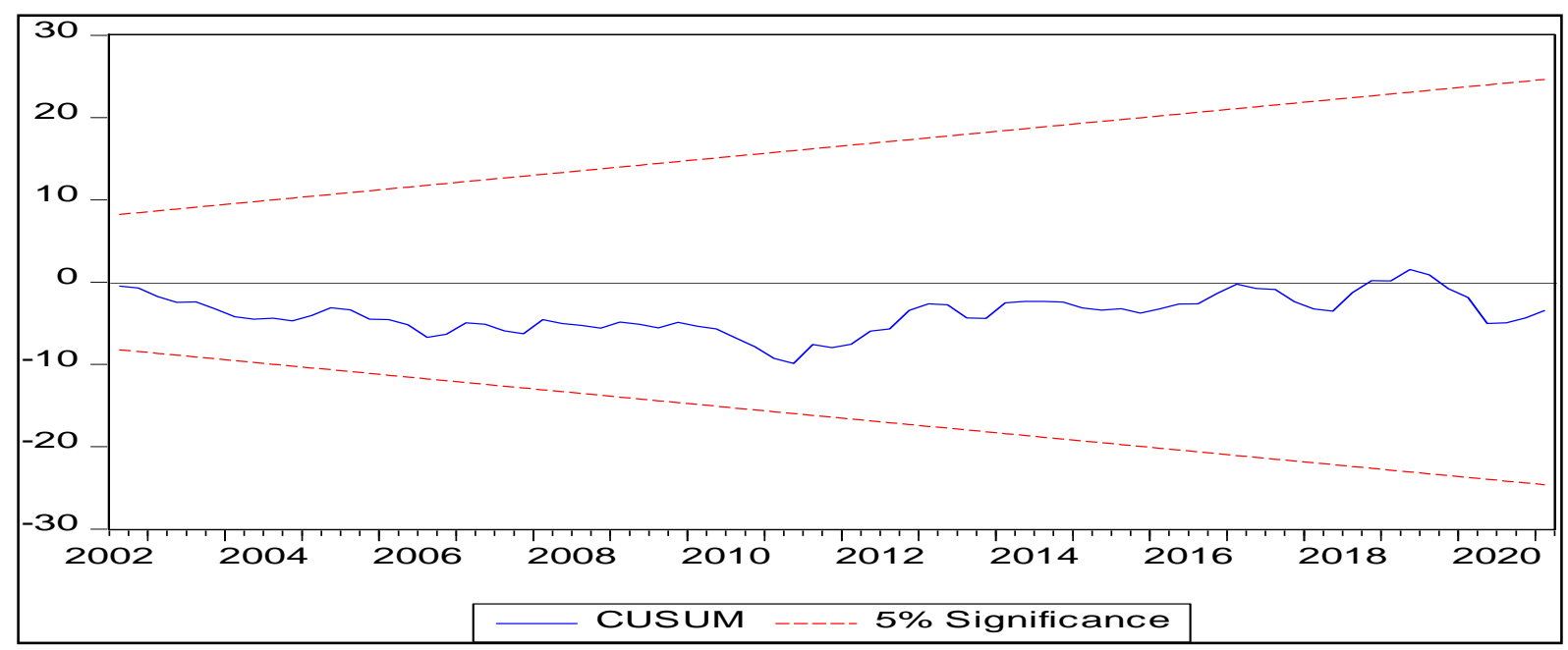

To test whether the variables of the model given in Equation (2) is cointegrated, we estimated the long-run form of the ARDL and applied bounds testing. The long-run form of the ARDL model can be written as follows:

$$
\Delta C A D_{t}=\theta_{0}+\sum_{i=1}^{n} \theta_{1 i} \Delta C A D_{t-i}+\sum_{i=0}^{n} \theta_{2 i} \Delta X_{t-i}+\lambda_{1} C A D_{t-1}+\lambda_{2} X_{t-1}+\varepsilon_{1 t}
$$

where $\Delta$ is difference operator. The null hypothesis in the ARDL bounds test is that the level variables in Equation (3) $\left(C A D_{t-1}\right.$ and $\left.X_{t-1}\right)$ are not cointegrated and the alternative hypothesis says that there is cointegration among these variables. If the computed F-statistic is greater than the upper bound (I(1)), critical values provided by Pesaran et al. (2001), the null hypothesis of no cointegration is rejected and we conclude that the variables of the model are cointegrated implying that there exists a long-run relationship among these variables. But if the computed F-statistic is smaller than the lower bound $(\mathrm{I}(0))$, critical values, the null hypothesis of no cointegration cannot be rejected.

Table 3 provides bounds testing results. Examination of Table 3 shows that the null hypothesis of no level relationship among the variables of equation (3) is rejected at $1 \%$ level of significance by F-statistic and rejected at $2.5 \%$ level of significance by t-statistic. Combining these two findings, we conclude that there is a long-run relationship among the variables of CAD model according to the ARDL bounds testing. 
Table 3. ARDL Bounds Test Results

\begin{tabular}{|c|c|c|c|c|c|c|c|c|}
\hline \multicolumn{4}{|c|}{ F-Bounds Test } & \multicolumn{4}{c|}{ t-Bounds Test } & Significance \\
\cline { 1 - 7 } Test Statistic & Value & $\mathrm{I}(0)$ & $\mathrm{I}(1)$ & Test Statistic & Value & $\mathrm{I}(0)$ & $\mathrm{I}(1)$ & Level \\
\hline F-statistic & $5.1027 *$ & 1.95 & 3.06 & t-statistic & -5.0645 & -2.57 & -4.4 & $10 \%$ \\
\hline & & 2.22 & 3.39 & & & -2.86 & -4.72 & $5 \%$ \\
\hline & & 2.48 & 3.7 & & & -3.13 & -5.02 & $2.5 \%$ \\
\hline & & 2.79 & 4.1 & & & -3.43 & -5.37 & $1 \%$ \\
\hline
\end{tabular}

Note: *, ** indicate statistical significance at $1 \%$ and $2.5 \%$ levels. I( 0$)$ and $\mathrm{I}(1)$ shows lower bound and upper bound asymptotic Critical Values respectively.

\section{RESULTS AND DISCUSSIONS}

The ARDL bound test results have shown that there is cointegration between CADs and their determinants in the previous section. Having confirmed the presence of a long-run relationship among variables in Equation (1), we estimated the autoregressive distributed lag-error correction (ARDL-EC) model given in Equation (3). This section presents the estimates obtained from the ARDL-ECM model on the long-run and short-run determinants of CADs. Table 4 presents the long-run and short-run estimates of Equation (3).

Examination of Table 4 provides a number of insights into the determinants of CADs in Turkey. First, the coefficient of lagged error correction term is negative and statistically significant, indicating that deviations in current account balance adjust to its long-run equilibrium level. As well known, the presence of a long-run relationship among variables implies the existence of an error correction mechanism. The coefficient of is also called as the speed of adjustment term and is equal to -0.319 . This figure implies that the speed of adjustment is slow and that about $32 \%$ of deviation in the current account balance will be corrected within one quarter.

Secondly, the results show that, in the long run, the coefficients of only three variables (GM, REX, FD) out of eight determinants of CADs assume statistically significant coefficients. According to findings in Table 4, in the long run, a rise in gold imports, reel effective exchange rate, and financial development cause CADs increase in Turkey. The fact that an increase in REX and GM deteriorate CADs is reasonable since an increase in REX implies an appreciation of Turkish currency, and traditionally Turkish people use gold as a saving instrument. However, it is surprising that the deepening of financial development also leads to the worsening of CADs. This might be because the Turkish financial markets are still small in size compared to global financial markets; they could not achieve full integration to both world financial and real markets. It is also surprising that energy imports (EM), short-term (PI) and long-term (FDI) capital inflows, trade openness (OP), and production level (RGDP) do not seem to have a significant effect on CADs in the long run. Among these variables, although they are statistically not significant, the coefficients of OP and RGDP assumed negative signs implying that increases in the level of production and international trade may play a positive role in reducing CADs. 
Table 4. Long-run and Short-run Results of ARDL model

\begin{tabular}{lccc}
\hline \multicolumn{4}{c}{ Panel A: Long-run Coefficients-Dependent Variable is CAD } \\
\hline Variable & Coefficient & Std. Error & t-Statistic \\
EM & -0.322 & 0.684 & -0.471 \\
GM & $-2.001^{*}$ & 0.699 & -2.864 \\
PI & -0.620 & 0.460 & -1.347 \\
FDI & -0.136 & 0.345 & -0.393 \\
RGDP & 2.940 & 3.107 & 0.946 \\
REX & $-13.040^{*}$ & 4.431 & -2.943 \\
OP & 0.240 & 0.155 & 1.555 \\
FD & $-0.077^{*}$ & 0.025 & -3.066
\end{tabular}

\begin{tabular}{|c|c|c|c|}
\hline \multicolumn{4}{|c|}{ Panel B: Short-run Coefficients-Dependent Variable is $\triangle \mathrm{CAD}$} \\
\hline Variable & Coefficient & Std. Error & t-Statistic \\
\hline $\mathrm{C}$ & $16.696^{*}$ & 2.274 & 7.343 \\
\hline$\Delta \mathrm{EM}$ & $-0.527 *$ & 0.236 & -2.233 \\
\hline$\Delta \mathrm{GM}$ & $-0.967 *$ & 0.142 & -6.787 \\
\hline$\Delta \mathrm{PI}$ & $0.114^{*}$ & 0.117 & 0.974 \\
\hline$\Delta \mathrm{PI}(-1)$ & $0.273^{*}$ & 0.118 & 2.317 \\
\hline$\Delta \mathrm{FDI}$ & $-0.068 *$ & 0.040 & -1.729 \\
\hline$\Delta \mathrm{FDI}(-1)$ & $-0.098 *$ & 0.039 & -2.502 \\
\hline$\Delta \mathrm{FDI}(-2)$ & $-0.159 *$ & 0.037 & -4.276 \\
\hline$\Delta \mathrm{RGDP}$ & $-18.744 *$ & 5.164 & -3.630 \\
\hline$\Delta \mathrm{RGDP}(-1)$ & $-11.229 *$ & 3.335 & -3.367 \\
\hline$\Delta$ RGDP(-2) & $-14.090^{*}$ & 3.482 & -4.046 \\
\hline$\Delta \mathrm{RGDP}(-3)$ & $-15.777^{*}$ & 4.169 & -3.784 \\
\hline$\Delta \mathrm{FD}$ & $-0.091 *$ & 0.019 & -4.753 \\
\hline$E C T_{t-1}$ & $-0.319 *$ & 0.045 & -7.129 \\
\hline \multicolumn{4}{|c|}{ Diagnostic Statistics } \\
\hline R-squared & 0.685 & F-statistic & $13.883^{*}$ \\
\hline Adjusted R-squared & 0.636 & Durbin-Watson & 1.931 \\
\hline Heteroscedasticity (21) & 18.459 & Funtional form: RESET test & 0.292 \\
\hline Autocorrelation test (2) & 1.1633 & Normality: Jarque-Berra test & 1.140 \\
\hline
\end{tabular}

Note: : $* * *, * * *$ indicate statistical significance at $1 \%$ and $5 \%$ and $10 \%$ levels. $\Delta$ is the first diffrence operator. Autocorrelation test is the Breusch-Godfrey LM test. Heteroscedasticity is tested using Harvey test.

Thirdly, the Panel B of Table 4 presents short-run coefficients of the model given in equation (3). It is worth mentioning that the dependent variable in the short-run (long-run) part of the ARDL-EC model is the first difference (level) of CADs variable ( $\triangle \mathrm{CAD}$ ). The results show that, in contrast to long-run determinants of CADs, all right hand side variables except REX and OP have a statistically significant effect on the CADs in the short-run. Reel effective exchange rate, although it has a negative a statistically significant effect on the level of CADs, it does not have any short-run effect on the first difference of CADs. There is also no short-run relationship between $\triangle \mathrm{CAD}$ and international trade openness variable $\Delta \mathrm{OP}$. Financial development $(\Delta \mathrm{FD})$ and gold imports $(\Delta \mathrm{GM})$ variables have a statistically significant and negative effect on CADs $(\triangle \mathrm{CAD})$ in the short-run as observed in the long-run case. However, energy imports $(\triangle \mathrm{EM})$, foreign direct investment $(\Delta \mathrm{FDI})$, economic groth $(\Delta \mathrm{RGDP})$, and 
portfolio investment $(\Delta \mathrm{PI})$ variables have a negative (only $\Delta \mathrm{PI}$ has a positive effect) and significant effect on CADs $(\triangle \mathrm{CAD})$ only in the short-run.

Fourthly, examination of the diagnostic statistics associated with CAD model in Table 4 indicates that the estimated model is stable and passes diagnostic tests including normality, autocorrelation, heteroscedasticity and functional form. The coefficient of determination of ARDL-EC model shows that approximately $69 \%$ of the change in dependent variable is explain by independent variables given in Panel B of Table 4.

\section{CONCLUSION}

This study investigated the determinants of CADs using the autoregressive distributed lag-error correction model for Turkish data over the period of 1996Q1 to 2021Q1. Considering the timeseries properties of the study, first, the integration level of variables is determined using unit root tests of ADF, PP, and KPSS. Having found that the dataset is composed of I(0) and I(1) variables, we used the ARDL bounds testing to test for cointegration at the second step. Then we estimated the CAD model using the ARDL-EC model to examine both the long-run and short-run determinants of CADs. The results of the study have shown that while gold imports, energy imports and short-term and long-term capital inflows have statistically significant and deteriorating (improving effect in case of portfolio investments) effect on CADs, among these variables only gold imports have a statistically significant and negative effect on CADs. The other two important variables that have a significant and negative effect on CADs in the long term are real effective exchange rates and financial development. Interestingly, openness proxy, which is being used as a measure of international trade integration of a country to the world economy, exerts no effect on CADs neither in the long-term and nor in the short-term.

\section{REFERENCES}

Ağır, H., Özbek, S., \& Türkmen, S. (2020). Türkiye'de cari işlemler dengesinin dinamikleri: VAR analizi. Maliye Araştırmaları Dergisi, 6(2), 57-66.

Aka, K. (2020). Cari açığı belirleyen faktörler: Türkiye ekonomisi üzerine ampirik bir uygulama. Anemon Muş Alparslan Üniversitesi Sosyal Bilimler Dergisi, 8(5), 15711583.

Barbaros, M., Kalaycı, S., \& Bakır, D. (2020). Türkiye'de sıcak para girişleri ve cari açık arasındaki ilişki, Üçüncü Sektör Sosyal Ekonomi Dergisi, 55(4), 2462-2477.

Bari, B. (2021). "Sustainability of current account deficit in Turkish economy". 311-322. In economic social and business issues evidence from developing world. Eds. Jamil, S. T., Dikmen, F.H., \& Köktaş, A.M. Ijopec Publication, UK.

Baş, G., \& Kara, M. (2020). The effects of macroeconomic factors on current account deficit: A time series analysis for Turkey. International Journal of Social Science Research, 9 (1), 36-47. 
Bitzis, G., Paleologos, J. M., \& Papazoglou, C. (2008). The determinants of the Greek current account deficit: The EMU experience. Journal of International and Global Economic Studies, 1(1), 105-122.

Demir, M. (2013). Enerji ithalatı cari açık ilişkisi, var analizi ile Türkiye üzerine bir inceleme. Akademik Araştırmalar ve Çalışmalar Dergisi, 5(9), 2-27.

Demirbaş, M., Türkay, H., \& Türkoğlu, M. (2009). Petrol fiyatlarındaki değişmelerin Türkiye'nin cari açığı üzerine etkisinin analizi. Süleyman Demirel Üniversitesi İII.B.F Dergisi, 14(3), 289-299.

Engle, R. and Granger, C. (1987). Cointegration and Error Correction: Representation, Estimation and Testing. Econometrica, 55(2), 251-276. http://dx.doi.org/10.2307/1913236.

Erdoğan, S., \& Bozkurt, H. (2009). Türkiye'de cari açığın belirleyicileri: Mgarch modelleri ile bir inceleme. Maliye ve Finans Yazıları, 1(84), 135-172.

Erkılıç, S. (2006). Türkiye’de cari açı̆̆ın belirleyicileri, T.C. Merkez Bankası, İstatistik Genel Müdürlüğü, Uzmanlık Yeterlik Tezi, Ankara.

Gacener Atış, A., \& Saygıll, F. (2014). Türkiye'de Cari Açı̆̆ın Belirleyicilerinin Ampirik Analizi, Sosyoekonomi, 2014-1, 87-104.

İrhan, H. B., Alacahan, N. D., \& Korap, L. (2011). An empirical model for the Turkish trade balance: New evidence from ARDL bounds testing analyses, Ekonometri ve İstatistik, $14,38-61$.

Johansen, S. (1988). Statistical analysis of cointegration vectors. Journal of Economic Dynamics and Control, 12(2-3), 231-254.

Johansen, S., \& Juselius, K. (1990). Maximum likelihood estimation and inference on cointegration - With applications to the demand for money. Oxford Bulletin of Economics and Statistics, 52(2), 169-210.

Korucu Gümüşoğlu, N., \& Alçın, S. (2019). The impact of capital flows on current account deficit for Turkey, Journal of Life Economics, 6(1), 21-34, DOI: 10.15637/jlecon.6.003.

Kurniadi, A.P., Aimon, H., \& Sentosa, S. U. (2018). On the sustainability of current account deficits in Indonesia: Error correction mechanism approach. International Journal of Scientific and Research Publications, 8(5), 215-221, http://dx.doi.org/10.29322/IJSRP.8.4.2018.p7734.

Nkoro, E., \& Uko, A. K. (2016). Autoregressive Distributed Lag (ARDL) cointegration technique: application and interpretation, Journal of Statistical and Econometric Methods, 5(4), 63-91.

Nurudeen, A. (2017). Does Okun's law exist in Nigeria? Evidence from the ARDL bounds testing approach. Contemporary Economics, ISSN 2300-8814, University of Finance 
and Management in Warsaw, Faculty of Management and Finance, Warsaw, 11(2), 131144.

Pesaran, M. H., \& Shin, Y. (1999). An autoregressive distributed lag modeling approach to cointegration analysis. In S. Strøm (Ed.), Econometrics and economic theory in the 20th century: The Ragnar Frisch Centennial Symposium. Eeconometric society monographs 31, 1-31). Cambridge, UK: Cambridge University Press.

Pesaran, M. H., Shin, Y., \& Smith, R. J. (2001). Bounds testing approaches to the analysis of level relationships. Journal of Applied Econometrics, 16(3), 289- 326.

Sahoo, M., Mallick, H., \& Mahalik, M. K. (2020). What deteriorates India's current account balance: crude oil imports or gold imports?, Applied Economics Letters, 27(13), 11071111, DOI: 10.1080/13504851.2019.1673294.

Sarıtaş, H., Genç, A., \& Avcı, T. (2018). Türkiye'de enerji ithalatı, cari açık ve büyüme ilişkisi: Var ve Granger Nedensellik analizi. The International Journal of Economic and Social Research, 14(2), 181-199.

Topalli, N., \& Doğan, İ. (2016). The structure and sustainability of current account deficit: Turkish evidence from regime switching, The Journal of International Trade \& Economic Development, 25(4), 570-589, DOI: 10.1080/09638199.2015.1090472.

Uysal, D., Yılmaz, K.Ç., \& Taş, T. (2015). Enerji ithalatı ve cari açık ilişkisi: Türkiye örneği. Anemon MŞÜ Sosyal Bilimler Dergisi, 3(1), 63-78.

Yurdakul, F., \& Cevher, E. (2015). Determinants of current account deficit in Turkey: The conditional and partial granger casuality approach, Procedia Economics and Finance, $26,92-100$

Yücel, Y. (2003). Dynamics of the current account of balance of payments in Turkey?, 7. İktisat Kongresi, ODTÜ, Ankara. 